\title{
Pengawetan Kayu Karet Menggunakan Asap Cair dan Ekstrak kunyit Dengan Teknik Perendaman Dingin
}

\section{Preservation of Rubber Wood by Using Liguid SMoke With Cold SOAKING TECHNIQUE}

\author{
Sherly Hanifarianty ${ }^{1, *}$ dan Afrizal Vachlepi ${ }^{2}$ \\ ${ }^{1}$ Balai Penelitian Teknologi Karet, PT. Riset Perkebunan Nusantara \\ Jalan Salak Nomor 1, Bogor 16151, Jawa Barat \\ ${ }^{2}$ Pusat Penelitian Karet Sembawa, PT. Riset Perkebunan Nusantara \\ "Pos el: sherlyhanifarianty@yahoo.co.id
}

\begin{tabular}{|c|c|}
\hline ARTICLE INFO & Abstract \\
\hline Article history & Rubber wood (Hevea brasiliensis) is a wood with low durability wood. \\
\hline 2019-04-22 & $\begin{array}{l}\text { not environmental friendly. This study was conducted to evaluate the } \\
\text { potential of liquid smoke from pyrolysis of palm oil kernel and turmeric }\end{array}$ \\
\hline Received in revised form date & extract as wood preservatives. Rubber wood was soaked in $5 \%$ w/v of \\
\hline 2019-06-11 & $\begin{array}{l}\text { liquid smoke and turmeric extract, respectively for } 2,8 \text {, and } 14 \text { days } \\
\text { which preservation was carried out for six months. Formaline and }\end{array}$ \\
\hline Accepted date & boric acids was used for comparison as well. The used parameters were \\
\hline 2019-07-04 & preservative retention, moisture content during storage, color changes, \\
\hline Available online date & $\begin{array}{l}\text { and damage level. The results indicated that the longer the immersion, } \\
\text { the greater the preservative retention and water content. Turmeric }\end{array}$ \\
\hline November 2019 & $\begin{array}{l}\text { extract and liquid smoke provided a brownish yellow and light brown } \\
\text { color. In general, liquid smoke for two days of immersion adequate for } \\
\text { six months preservation whereas turmeric acid for two months. }\end{array}$ \\
\hline
\end{tabular}

Keywords: Rubber wood, Cold soaking, Formaline, Boric acid, Turmeric extracts, Liquid smoked

Kata kunci:

Kayu karet

Rendaman dingin

Formalin

Boraks

Ekstrak ekstrak kunyit

Asap cair

\begin{abstract}
Abstrak
Tingkat keaweten kayu karet (Hevea brasiliensis) termasuk dalam kelas awet rendah. Pada umumnya kayu karet diawetkan dengan bahan-bahan kimia yang relatif tidak ramah lingkungan. Penelitian ini dilakukan untuk mengetahui potensi asap cair hasil pirolisis cangkang kelapa sawit dan ekstrak ekstrak kunyit sebagai bahan pengawet kayu karet. Kayu karet masing-masing direndam dengan $5 \% \mathrm{~b} / \mathrm{v}$ asap cair dan ekstrak kunyit selama 2, 8, dan 14 hari dengan lama pengawetan selama enam bulan. Sebagai pembanding, kayu karet diawetkan pula dengan formalin dan boraks. Parameter yang digunakan, yaitu retensi bahan pengawet, kadar air penyimpanan, perubahan warna, dan dejarat kerusakan. Hasil penelitian menunjukkan bahwa semakin lama waktu rendaman, semakin besar retensi pengawetnya dan kadar air di dalam kayu karet. Ekstrak kunyit dan asap cair masing-masing menyebabkan warna kuning kecoklatan dan coklat terang. Perlakuan menggunakan asap cair selama dua hari perendaman memadai untuk pengawetan selama enam bulan, sedangkan ekstrak kunyit hanya dua bulan.
\end{abstract}




\section{PENDAHULUAN}

Kayu karet merupakan salah satu hasil samping yang potensial dari perkebunan karet alam, selain getah karet atau lateks. Dengan luas areal perkebunan karet Indonesia yang mencapai 3,5 juta hektar, potensi kayu karet pada tahun 2010 mencapai 2,8 juta $\mathrm{m}^{3}$ (Ditjenbun 2010). Dengan potensi tersebut, kayu karet dapat dijadikan alternatif pengganti kayu hutan yang cenderung semakin terbatas.

Keawetan kayu karet sangat rendah, termasuk kelas awet $\mathrm{V}$ dengan rata-rata keawetan hanya sembilan bulan (Barly, Ismanto, and Martono 2011). Kayu karet merupakan salah satu kayu yang menjadi sumber makanan dan tempat berkembang biak serangga dan jamur sehingga cepat rusak. Untuk penggunaan di dalam dan luar ruangan, misal untuk bahan bangunan, kayu perlu diawetkan agar tahan lama. Pengawetan merupakan proses pemasukan bahan pengawet ke dalam kayu dengan tujuan mencegah serangan dari faktor perusak biologis (Barly, Ismanto, and Martono 2011).

Bahan pengawet untuk kayu karet yang umum digunakan adalah formalin dan boraks (Barly, Ismanto, and Martono 2011). Kayu karet dapat pula diawetkan menggunakan ammonium karbonatboraks 8 dan $10 \%$ di dalam ruangan selama 3- 4 minggu (Barly and Martono 2010). Seng khlorida dikromat juga digunakan sebagai pengawet kayu karet dengan konsentrasi $3,5 \%$ selama 12 bulan (Barly and Ismanto 2009). Penggunaan asam borat sebagai pengawet kayu karet dengan metode perendaman panas dapat meningkatkan nilai penetrasi, retensi dan stabilitas dimensi (Putri, Herawati, and Batubara 2013). Kayu karet dapat pula diawetkan menggunakan boron (Barly and Permadi 1988). Bahanbahan pengawet kayu karet tersebut umumnya berbahaya bagi lingkungan.
Penggunaan bahan organik sebagai pengawet yang lebih ramah bagi lingkungan dan aman, menjadi alternatif yang menarik.

Selama ini bahan pembeku untuk karet menggunakan asap cair dari proses pirolisis cangkang kelapa sawit yang mengandung senyawa aktif fenol dan gugus karbonil berfungsi sebagai antibakteri dan jamur (Solichin, Anwar, and Tedjaputra 2007). Penggunaan asap cair berfungsi pula sebagai pengawet ikan tongkol asap (Lala, Pongoh, and Taher 2017), pengawet ikan nila (Jamilatun et al. 2016), dan pengawet bahan makanan (Sugihartono 2009). Sementara itu ekstrak kunyit yang mengandung pigmen kurkumin dapat digunakan sebagai pengawet organik untuk makanan, tekstil, dan obat-obatan (Koswara 2009). Senyawa bioaktif yang terdapat di dalam ekstrak kunyit adalah kurkumin, desmetoksikumin, dan bidestometoksikumin (Koswara 2009). Diketahui bahwa ekstrak kunyit digunakan pula sebagai bahan pengawet untuk daging dan ikan (Purwani and Muwakhidah 2008) dan untuk pengawet ikan Layang (Decapterus sp) (Pasaraeng, Abidjulu, and Runtuwene 2013). Sementara itu, pengawetan kayu karet menggunakan asap cair dengan metode perendaman panas selama satu jam dapat menjaga keawetannya (Vachlepi, Suwardin, and Hanifarianty 2015) tetapi biayanya mahal. Pemanfaatan asap cair dan kukurmin sebagai pengawet kayu dengan metode perendaman dingin belum pernah dilakukan.

\section{BAHAN DAN METODE}

Penelitian dilakukan di Laboratorium Teknologi Balai Penelitian Sembawa November 2012 - April 2013. Tujuan penelitian ini adalah mengetahui potensi asap cair dan ekstrak kunyit sebagai 
pengawet organik kayu karet dengan metode perendaman dingin.

\section{Bahan}

Ranting kayu karet (Hevea brasiliensis) diperoleh dari kebun riset Balai Penelitian Sembawa, ukuran panjang $100 \mathrm{~mm}$ dan diameter $30 \mathrm{~mm}$. Bahan pengawet kimia yang digunakan, yaitu boraks dan formalin teknis, sedangkan asap cair merupakan hasil dari pirolisis cangkang kelapa sawit dari PT. Global Deorub Industry. Untuk ekstrak kunyit digunakan setelah dibersihkan, umbi kunyit dihaluskan dengan blender, lalu dikeringkan selama satu minggu dengan oven pada suhu $60{ }^{\circ} \mathrm{C}$.

\section{Pengawetan}

Kayu karet masing-masing di rendam di dalam larutan 5\% (b/v) asap cair dan ekstrak kunyit pada suhu $27 \mathrm{n}{ }^{\circ} \mathrm{C}$ selama 2, 8, dan 14 hari. Tinggi larutan pengawet $10 \mathrm{~cm}$ di atas permukaan tumpukan kayu. Contoh uji yang sudah direndam dengan bahan pengawet kemudian dianginanginkan dalam ruangan. Lama pengamatan dilakukan selama enam bulan.

\section{Pengujian}

\section{Retensi bahan pengawet}

Pengukuran retensi dilakukan untuk mengetahui banyaknya bahan pengawet yang masuk ke dalam kayu. Perhitungan retensi menggunakan (Barly, Ismanto, and Martono 2011):

$$
R=\frac{B o-B a}{V} \times C R=\frac{B o-B a}{V} \times C
$$

dimana:

$\mathrm{R}=$ Retensi $\left(\mathrm{kg} / \mathrm{m}^{3}\right)$

$\mathrm{Bo}=$ Berat kayu sesudah diawetkan $(\mathrm{kg})$

$\mathrm{Ba}=$ Berat kayu sebelum diawetkan $(\mathrm{kg})$
$\mathrm{C}=$ Konsentrasi larutan bahan pengawet (\%)

$\mathrm{V}=$ Volume kayu $\left(\mathrm{m}^{3}\right)$

\section{Kadar air}

Penetuan Kadar air dilakukan dengan cara menimbang contoh uji dalam keadaan segar untuk memperoleh berat awal $(\mathrm{Ba})$. Contoh uji dikering di suhu ruangan selama satu minggu, kemudian ditimbang hingga diperoleh berat konstan (Bko). Kadar air dihitung dengan (Barly, Ismanto, and Martono 2011):

$$
\begin{array}{r}
(\%) K a=\frac{B a-B k o}{B k o} \times 100 \\
(\%) K a=\frac{B a-B k o}{B k o} \times 100
\end{array}
$$

dimana:

$\mathrm{Ka}=$ kadar air kayu (\%)

$\mathrm{Ba}=$ berat awal kayu sebelum kering udara $(\mathrm{g})$

$\mathrm{Bko}=$ berat kayu kering udara $(\mathrm{g})$

\section{Perubahan warna}

Perubahan warna kayu karet diamati berdasarkan buku panduan 'Munsell Color ${ }^{\circledR}$ Charts'.

\section{Proteksi terhadap kerusakan}

Proteksi terhadap kerusakan merupakan skala yang digunakan untuk mengukur kerusakan kayu faktor perusak biologis berdasarkan analisis visual. Untuk kayu karet yang tidak menunjukkan adanya kerusakan diberi nilai 100. Apabila terdapat serangan dipermukaan kayu diberikan nilai sebagai 90 . Nilai 80 apabila ditemukannya banyak serangan di permukaan kayu. Keadaan serangan yang masuk tetapi belum meluas dapat diberikan nilai 70 , sedangkan jika serangan sudah meluas diberi nilai 40. Untuk kayu yang hancur diberi nilai 0 . Tabel 1 merupakan panduan untuk pengamatan kerusakan kayu karet. 
Tabel 1. Skor derajat kerusakan pada kayu karet

\begin{tabular}{cc}
\hline Nilai & Keadaan Serangan \\
\hline 100 & Tidak ada serangan \\
90 & Ada di permukaan \\
80 & Banyak di permukaan \\
70 & Masuk tetapi belum meluas \\
40 & Masuk dan sudah meluas \\
0 & Hancur \\
\hline
\end{tabular}

Sumber: (Barly, Ismanto, and Martono 2011)

\section{HASIL DAN PEMBAHASAN \\ Retensi bahan pengawet}

Hasil perhitungan retensi pengawet dapat dilihat pada Gambar 1. Hasil pengukuran menunjukkan bahwa semakin lama perendaman, retensi kayu karet, semakin meningkat (Gambar 1).

Dari Gambar 1 dapat dilihat bahwa retensi tertinggi ditunjukkan dari lama perendaman 14 hari menggunakan asam boraks, sedangkan terendah ditunjukkan dari lama perendaman dua hari menggunakan formalin. Retensi berpengaruh terhadap penyerapan bahan pengawet di dalam kayu. Semakin lama waktu penyimpanan, semakin banyak bahan pengawet yang masuk ke dalam kayu (Suheryanto 2010). Terserapnya bahan pengawet ke dalam kayu, meningkatkan keefektifan bahan pengawet tersebut terhadap serangan perusak kayu karet.

Lama perendaman dapat meningkatkan retensi pada kayu karet untuk semua jenis bahan pengawet. Dari Gambar 1 dapat dilihat bahwa retensi kayu dari perendaman delapan hari berbeda dengan perlakuan perendaman 14 hari untuk boraks dan asap cair. Boraks memiliki retensi tertinggi, berbeda dengan asap cair, sedangkan untuk bahan pengawet lainnya retensi kayu dari perendaman delapan hari tidak terlalu berbeda dengan perlakuan perendaman 14 hari. Hal tersebut disebabkan karena boraks lebih mudah meresap ke dalam kayu. Untuk asap cair dan ekstrak kunyit memiliki nilai retensi hampir sama, tetapi tidak lebih tinggi dibandingkan boraks. Pada proses rendaman, retensi yang dicapai pada semua perlakuan melebihi retensi yang disarankan (Barly, Ismanto, and Martono 2011), yaitu $8,0 \mathrm{~kg} / \mathrm{m}^{3}$.

Retensi minimum yang disyaratkan untuk pemakaian di bawah atap dan di luar atap, yaitu masing-masing 8,2 dan 11,3 $\mathrm{kg} / \mathrm{m}^{3}$ (SNI, 1999). Hasil penelitian ini menunjukkan bahwa perendaman dua hari sudah memenuhi standar untuk pemakaian atap. Hasil penelitian menunjukkan bahwa besarnya retensi bahan pengawet yang larut dalam air untuk pemakaian di bawah atap berkisar antara 3,4-5,6 kg/m (Martawijaya and Abdurrohim 1984).

Retensi asap cair dan ekstrak kunyit yakni masing-masing sebesar 13,7 dan $15,4 \mathrm{~kg} / \mathrm{m}^{3}$, memenuhi syarat untuk kayu, yaitu $11,3 \mathrm{~kg} / \mathrm{m}^{3}$ (SNI, 1999).

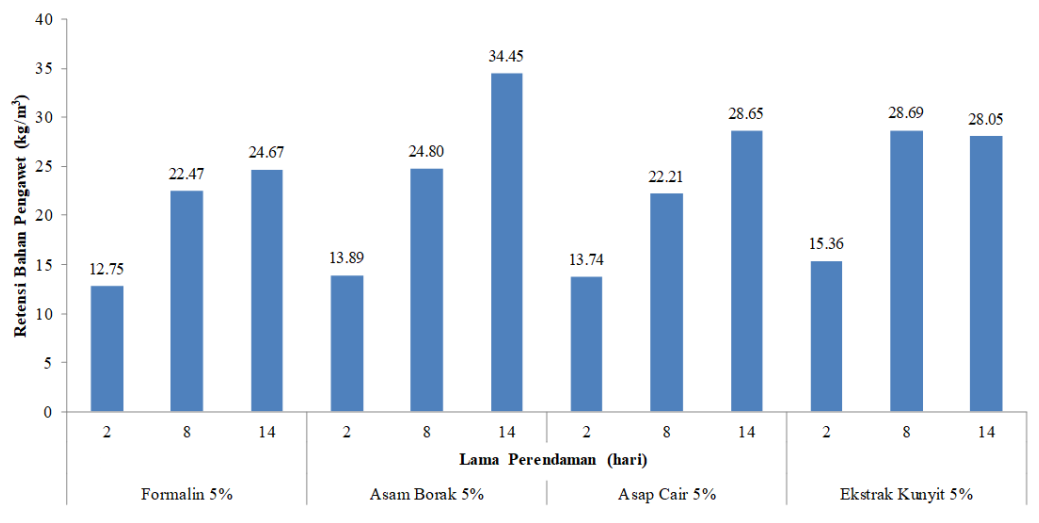

Gambar 1. Retensi kayu terhadap pengawet 


\section{Kadar air selama penyimpanan}

Kadar air yang terdapat di dalam kayu karet merupakan kadar air yang berasal dari bahan pengawet pada saat perendaman (Gambar 2.). Lama perlakuan rendaman dapat mempengaruhi kadar air kayu awal. Hal ini mungkin disebabkan kayu memiliki sifat higroskopis, sehingga bahan pengawet mudah terserap ke dalam kayu (Ardiansa, Ariyanti, and Hapid 2014). Kadar air menurun seiring dengan lama penyimpanan (Gambar 2.). Fenomena ini terjadi kemungkinan disebabkan oleh susut bobot, sehingga air dapat keluar selama dalam penyimpanan (Ardianto, Jamaluddin, and Wijaya 2017). Air dalam struktur molekul kayu memiliki peluang untuk keluar sehingga terjadilah susut bobot (Sugiman, Nu'man, and Sulistyowati 2014).

Secara umum, kayu karet yang diawetkan dengan ekstrak kunyit mempunyai kadar air tertinggi sebesar 25,7\% setelah 14 hari perendaman, sementara formalin memiliki kadar air terendah sebesar $1,8 \%$ setelah dua hari perendaman.
Lama perendaman memengaruhi kadar air yang terkandung di dalam kayu. Perendaman menggunakan bahan organik dapat menyerap bahan pengawetnya dengan baik, sehingga kadar air awal relatif lebih tinggi dibanding bahan kimia. Hal ini mungkin disebabkan oleh karakteristik kayu karet yang higroskopis (Ardiansa, Ariyanti, and Hapid 2014).

Bertambahnya bahan pengawet di dalam kayu setelah perendaman dapat memengaruhi kualitas kayu terhadap derajat kerusakan (Aini, Morisco, and Anita 2009). Penggunaan bahan pengawet yang tepat dapat menjaga kualitas kayu (Ardianto, Jamaluddin, and Wijaya 2017).

Sakin lama penyimpanan, kadar air di dalam kayu semakin berkurang. Hal ini disebabkan oleh sifat desorpsi yang dapat melepaskan air dalam kayu (Mardikanto, Karlina, and Bahtiar 2011). Pada bulan ke enam kadar air cenderung naik kembali 0,2 $-0,4 \%$, hal tersebut karena faktor lingkungan yang lembab (Haygreen and Bowyer 1989). Adanya gugus OH pada selulosa, hemiselulosa dan lignin pada kayu karet dapat mengikat air (Usman 2006).

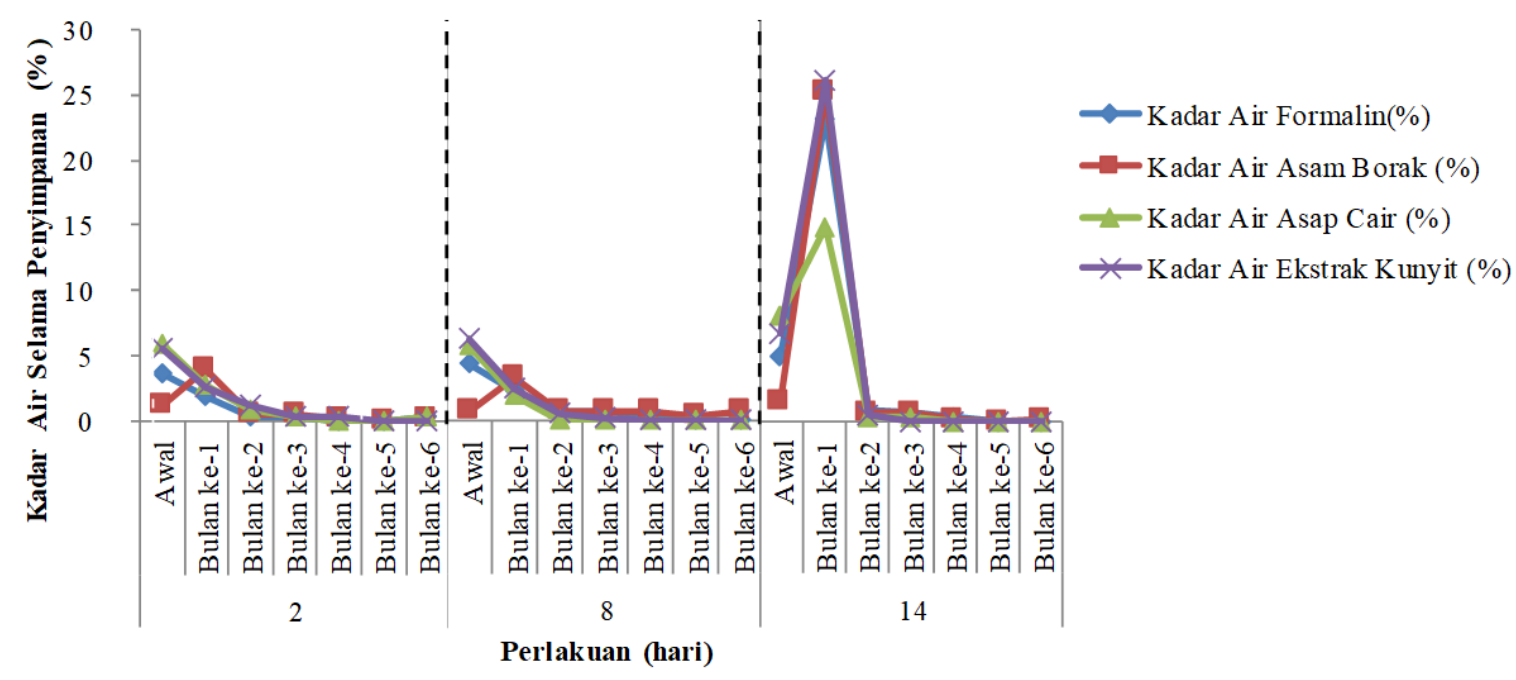

Gambar 2. Kadar air selama penyimpanan 


\section{Perubahan warna}

Setelah enam bulan penyimpanan, sampel kayu kontrol dan kayu dengan perlakuan perendaman formalin berubah warna menjadi coklat sangat pucat, kayu dengan perlakuan perendaman boraks berwarna kuning pucat, kayu dengan perlakuan perendaman ekstrak ekstrak kunyit berwarna kuning kecoklatan, sedangkan kayu dengan perlakuan perendaman asap cair berwarna coklat terang.

Perendaman menyebabkan terjadinya penyerapan zat warna ke dalam kayu. Di dalam kayu, zat warna dapat terdeposit dalam rongga atau mikro pori dalam jaringan kayu dan diduga dapat berikatan hidrogen dengan gugus hidroksil pada komponen kimia kayu (Muflihati et al. 2014). Perubahan tersebut disebabkan oleh pengaruh warna dari masing-masing bahan pengawet. Asap cair memberikan warna coklat karena adanya senyawa fenol dan karbonil (Solichin, Anwar, and Tedjaputra 2007), sedangkan ekstrak kunyit memberikan warna kekuningan, yang merupakan pigmen kurkumin yaitu desmethoxycurcumin dan bis-desmethoxycurcumin (Koswara 2009). Perubahan warna kayu karet pada beberapa perlakuan perendaman dapat dilihat pada Tabel 2 dan Gambar 3.

Tabel 2. Warna sampel kayu karet

\begin{tabular}{|c|c|c|c|c|}
\hline \multirow{2}{*}{ Perlakuan } & \multirow{2}{*}{$\begin{array}{c}\text { Lama Penyimpanan } \\
\text { (Bulan ke-) }\end{array}$} & \multicolumn{3}{|c|}{ Lama Perendaman (hari) } \\
\hline & & 2 & 8 & 14 \\
\hline \multirow[t]{2}{*}{ Formalin } & 1 & $\begin{array}{l}\text { sangat kuning } \\
\text { pucat }\end{array}$ & sangat kuning pucat & sangat kuning pucat \\
\hline & 6 & $\begin{array}{l}\text { sangat coklat } \\
\text { pucat }\end{array}$ & kuning pucat & sangat coklat pucat \\
\hline \multirow[t]{2}{*}{ Boraks } & 1 & $\begin{array}{l}\text { sangat kuning } \\
\text { pucat }\end{array}$ & sangat kuning pucat & sangat kuning pucat \\
\hline & 6 & kuning pucat & kuning pucat & kuning pucat \\
\hline \multirow{2}{*}{$\begin{array}{l}\text { Ekstrak } \\
\text { kunyit }\end{array}$} & 1 & $\begin{array}{l}\text { sangat kuning } \\
\text { pucat }\end{array}$ & sangat kuning pucat & sangat kuning pucat \\
\hline & 6 & kuning & kuning & coklat pucat \\
\hline \multirow[t]{2}{*}{ Asap cair } & 1 & $\begin{array}{l}\text { sangat kuning } \\
\text { pucat }\end{array}$ & sangat kuning pucat & sangat kuning pucat \\
\hline & 6 & coklat terang & coklat & coklat \\
\hline \multirow{2}{*}{ Kontrol } & 1 & $\begin{array}{l}\text { Sangat kuning } \\
\text { pucat }\end{array}$ & Sangat kuning pucat & $\begin{array}{l}\text { Sangat kuning } \\
\text { pucat }\end{array}$ \\
\hline & 6 & $\begin{array}{l}\text { Sangat coklat } \\
\text { pucat }\end{array}$ & Sangat kuning pucat & $\begin{array}{l}\text { Sangat kuning } \\
\text { pucat }\end{array}$ \\
\hline
\end{tabular}




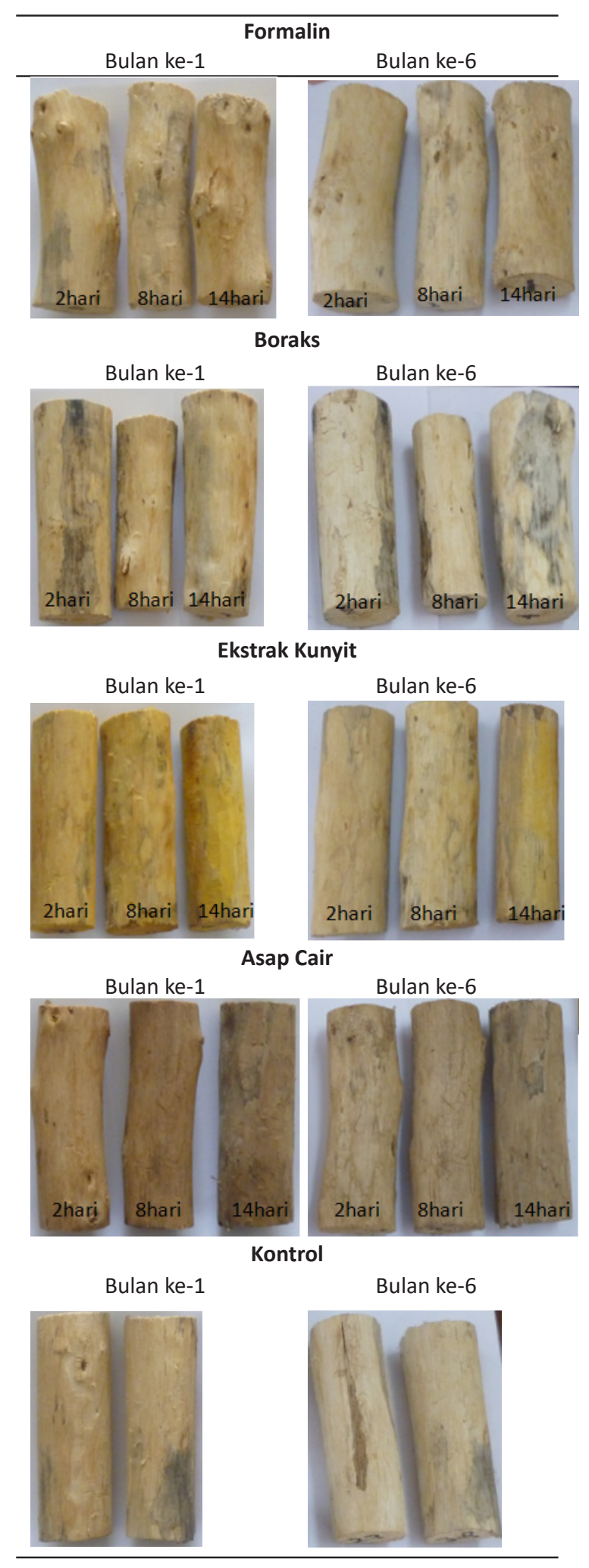

Gambar 3. Perubahan Warna Kayu Karet

\section{Proteksi terhadap kerusakan}

Proteksi terhadap kerusakan dapat disebabkan oleh serangan jamur, rayap kayu kering, dan bubuk kayu kering (Dumanau 2001). Proteksi terhadap kerusakan kayu karet setelah perendaman dapat dilihat pada Tabel 3. Perendaman dengan formalin dapat mempertahankan proteksi terhadap kerusakan kayu karet sebesar 100\%. Penggunaan boraks tidak memperlihatkan kerusakan sampai dengan bulan ke lima $(100 \%)$ di setiap variasi perendaman. Pada bulan ke enam derajat kerusakan menjadi $90 \%$ di setiap variasi waktu perendaman. Penggunaan bahan kimia berupa formalin sudah lazim digunakan untuk melindungi kayu karet dari serangan serangga perusak kayu (Barly and Permadi 1988). Penelitian juga menunjukkan bahwa larutan 5\% campuran soda abu - boraks $(1,0: 2,0)$ yang dinyatakan sebagai asam borat $\left(\mathrm{H}_{2} \mathrm{BO}_{3}\right)$ pada retensi $7,23 \mathrm{~kg} / \mathrm{m}$ terbukti efektif mencegah rayap tanah dan rayap kayu kering (Barly, Ismanto, and Martono 2011).

Penggunaan asap cair selama dua dan delapan hari perendaman tidak menunjukkan ada serangan serangga perusak kayu setelah kayu disimpan sampai enam bulan tetapi perlakuan 14 hari perendaman, derajat kerusakan kayu menurun menjadi 90\% pada tiga bulan penyimpanan, kembali menurun menjadi perlahan $70 \%$ pada enam bulan penyimpanan. Hal ini mungkin disebabkan air merupakan penyebab utama busuk pada tanaman (Yunasfi 2002). Faktor tersebut merupakan faktor lingkungan abiotik (tidak hidup).

Penggunaan ekstrak ekstrak kunyit juga memengaruhi proteksi terhadap kerusakan pada kayu karet di setiap variasi waktu perendaman. Hal tersebut menunjukkan tidak ada serangan serangga perusak kayu pada penyimpanan bulan ke satu dan ke dua. Perendaman selama dua 
dan delapan hari, menunjukkan proteksi terhadap kerusakan kayu turun menjadi 90\% pada bulan ke tiga sampai dengan bulan ke enam. Perendaman selama 14 hari proteksi terhadap kerusakan sebesar $90 \%$ kembali turun menjadi $80 \%$ pada bulan

\section{UCAPAN TERIMA KASIH}

Terima kasih disampaikan kepada Prof. Dr. Myrtha Karina Sancoyorini sebagai pembimbing dalam penulisan karya ilmiah dan Pusat Penelitian Karet Sembawa untuk penyiapan pendanaan dalam penelitian ini.

Tabel 3. Hasil proteksi terhadap kerusakan

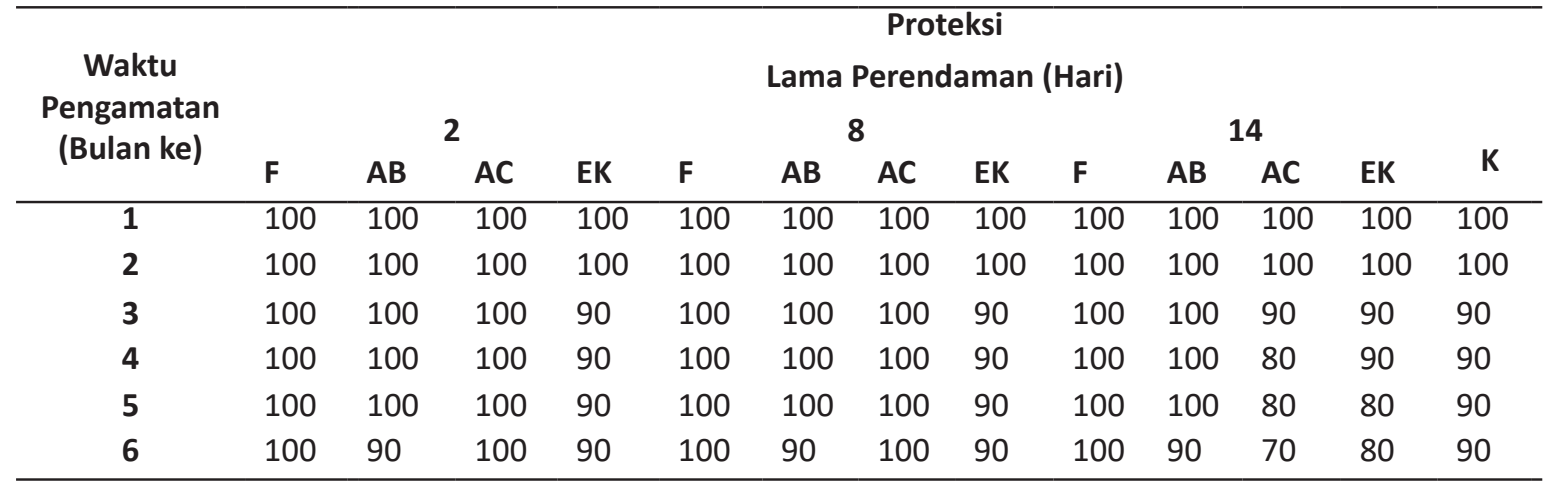

\section{Keterangan:}

F : Formalin

AB : Asam boraks

AC : Asap cair

EK : Ekstrak kunyit

K : Kontrol

ke lima dan ke enam. Untuk kontrol pada bulan ke satu dan dua menunjukkan tidak adanya serangan, tetapi turun menjadi $90 \%$ pada bulan ke tiga sampai dengan bulan ke enam.

\section{KESIMPULAN}

Dari hasil evaluasi retensi, warna, kadar air, dan derajat kerusakan kayu dapat disimpulkan bahwa perendaman selama dua hari dengan asap cair dapat mencegah kerusakan kayu karet selama enam bulan, sedangkan ekstrak kunyit hanya dua bulan. Penggunaan ekstrak ekstrak kunyit dan asap cair sebagai bahan pengawet menyebabkan warna kuning kecoklatan dan coklat terang.

\section{DAFTAR ACUAN}

Aini, N., Morisco, and Anita. 2009. "Pengaruh Pengawetan Terhadap Kekuatan dan Keawetan Produk Laminasi Bambu." Forum Teknik Sipil.

Ardiansa, Budi, Ariyanti, and Abdul Hapid. 2014. "Pengaruh Konsentrasi dan Lama Perendaman Kayu Sengon (Paraserianthes Falcataria L . Nielsen) Dalam Ekstrak Daun Sirsak (Annona Muricata L.) Terhadap Serangan Rayap Tanah (Coptotermes Sp.)."Warta Rimba 2 (1): 81-87.

Ardianto, Jamaluddin, and Mohammad Wijaya. 2017. "Perubahan Kadar Air Ubi Kayu Selama Pengeringan Menggunakan Pengering Kabinet." Jurnal Pendidikan Teknologi Pertanian 3: S112-16.

Barly, and Agus Ismanto. 2009. "Kefektifan Seng Khlorida-Dikromat Sebagai Bahan Pengawet Kayu." Jurnal Penelitian Hasil Hutan 26 (4): 332-41. 
Barly, Agus Ismanto, and Dominicus Martono. 2011. "Dayaguna Campuran Soda Abu-Boraks Sebagai Anti Jamur Biru dan Rayap." Jurnal Penelitian Hasil Hutan 29 (2): 179-88.

Barly, and D. Martono. 2010. "Efikasi Dua Senyawa Karbonat Terhadap Jamur Biru." In Prosiding 7 Basic Science National Seminar, III 247-254. Universitas Brawiajaya, Malang.

Barly, and Pipin Permadi. 1988. "Pengawetan Kayu Agathis, Bungur, Karet dan Tusam Dengan Metode Pencelupan." Jurnal Penelitian Hasil Hutan 5 (5): 303-6.

Ditjenbun. 2010. "Data Luas Perkebunan Karet."

Dumanau, J.F. 2001. Mengenal Kayu. Yogyakarta.

Haygreen, JG, and Bowyer. 1989. Hasil Hutan dan Ilmu Kayu: Suatu Pengantar. Penerjemah: Sutjipto A. H. Gadjah Mada University Press. Yogyakarta.

Jamilatun, Siti, Siti Salamah, Lia Aslihati, and Widya Suminar. 2016. "Pengaruh Perendaman Ikan Nila Dengan Asap Cair (Liquid Smoke) Terhadap Daya Simpan." In Seminar Nasional Sains Dan Teknologi, 1-8.

Koswara, Sutrisno. 2009. Pewarna Alami: Produksi dan Penggunaannya. http:// tekpan.unimus.ac.id/wp-content/uploads/2013/07/PEWARNAALAMI. pdf.

Lala, Neil Steward, Jenki Pongoh, and Nurmeilita Taher. 2017. "Penggunaan Asap Cair Cangkang Pala (Myristica Fragrans) Sebagai Bahan Pengawet Pada Pengolahan Ikan Tongkol (Euthinnus Affinis) Asap." Jurna Media Teknologi Hasil Perikanan 5 (1): 118-23.

Mardikanto, T.R, S Karlina, and E.F Bahtiar. 2011. Sifat Mekanis Kayu. Bogor. IPB Press.
Martawijaya, A, and S Abdurrohim. 1984. Spesifikasi Pengawetan Kayu Untuk Perumahan. Edisi keti. Bogor: Pusat Penelitisn dan Pengembangan Hasil Hutan.

Muflihati, Deded S Nawawi, Istie S Rahayu, and Wasrin Syafii. 2014. "Perubahan Warna Kayu Jabon Terwarnai Ekstrak Kulit Kayu Samak (Syzygium Inophyllum)." Jurnal Ilmu Dan Teknologi Kayu Tropis 12: 14-15.

Pasaraeng, Erling, Jemmy Abidjulu, and Max R J Runtuwene. 2013. "Pemanfaatan Rimpang Kunyit (Curcuma Domestica Val) Dalam Upaya Mempertahankan Mutu Ikan Layang (Decapterus Sp)." Jurnal MIPA UNSRAT 2 (2): 84-87.

Purwani, Eni, and Muwakhidah. 2008. "The Effect of Natural Preservatives as Formalin Substitute Toward The Organoleptic Characteristics and The Storage Time of Meat and Fish." Jurnal Penelitian Sains Dan Teknologi 9 (1): 1-14.

Putri, Nadya, Evalina Herawati, and Ridwanti Batubara. 2013. "Pengawetan Kayu Karet (Hevea Braziliensis MUELL Arg) Menggunakan Asam Borat (H3BO3) Dengan Metode Pengawetan Rendaman Panas Dingin," $1-8$.

Solichin, M, A Anwar, and N Tedjaputra. 2007. "Penggunaan Asap Cair Dalam Pengolahan RSS." Jurnal Peneltian Karet 25 (1): 83-94.

Sugihartono. 2009. “Asap Cair Sebagai Bahan Pengawet Pangan." Jurnal Riset Teknologi Industri 3 (6): 35038.

Sugiman, Abdul Hayyi Nu'man, and Emmy Dyah Sulistyowati. 2014. "Pengaruh Kadar Air Awal Kayu Jati dan Suhu Curing Perekat Pada Kekuatan Geser Sambungan Kayu Jati (Tectona Grandis) Secara Perekatan." Dinamika Teknik Mesin 4 (2): 96-102. 
Suheryanto, Dwi. 2010. "Pengaruh Konsentrasi Cupri Sulfat Terhadap Keawetan Kayu Karet.” In Seminar Rekayasa Kimia Dan Proses, 1-12.

Usman, F. 2006. Mengenal Sifat Fisika Kayu. Buku Ajar Fakultas Kehutanan UNTAN. Pontianak.

Vachlepi, Afrizal, Didin Suwardin, and Sherly Hanifarianty. 2015. "Pengawetan Kayu Karet Menggunakan Bahan Organik Dengan Teknik Perendaman Panas." Jurnal Penelitian Karet 33 (1): 57-64. https://doi. org/10.22302/jpk.v33i1.171.

Yunasfi. 2002. "Faktor-Faktor Yang Memengaruhi Perkembangan Penyakit dan Penyakit Yang Disebabkan Oleh Jamur." Universitas Sumatera Utara, $1-13$. 